Article

\title{
Sustainable Viticulture on Traditional ‘Baran’ Training System in Eastern Turkey
}

\author{
Muhammed Kupe ${ }^{1}$, Sezai Ercisli ${ }^{1, * \mathbb{C}}$, Mojmir Baron ${ }^{2}$ and Jiri Sochor ${ }^{2} \mathbb{D}$ \\ 1 Department of Horticulture, Faculty of Agriculture, Atatürk University, 25240 Erzurum, Turkey; \\ muhammed.kupe@atauni.edu.tr \\ 2 Department of Viticulture and Enology, Faculty of Horticulture, Mendel University in Brno, Valticka 337, \\ 69144 Lednice, Czech Republic; mojmirbaron@seznam.cz (M.B.); jiri.sochor@mendelu.cz (J.S.) \\ * Correspondence: sercisli@gmail.com; Tel.: +90-535-639-56-07
}

check for updates

Citation: Kupe, M.; Ercisli, S.; Baron, M.; Sochor, J. Sustainable Viticulture on Traditional 'Baran' Training System in Eastern Turkey. Sustainability 2021, 13, 10236. https://doi.org/10.3390/ su131810236

Academic Editor: Dalia Štreimikienè

Received: 26 August 2021

Accepted: 9 September 2021

Published: 14 September 2021

Publisher's Note: MDPI stays neutral with regard to jurisdictional claims in published maps and institutional affiliations.

Copyright: (c) 2021 by the authors. Licensee MDPI, Basel, Switzerland. This article is an open access article distributed under the terms and conditions of the Creative Commons Attribution (CC BY) license (https:/ / creativecommons.org/licenses/by/ $4.0 /)$.
Abstract: Erzincan plain is one of the most fascinating regions in Turkey for plant biodiversity. The area is very rich in terms of gene, species and ecosystem diversity. Having a number of natural habitats, mountains, etc., the region is one of the richest regions in Turkey for plant endemism as well. In northern parts of the region, in particular in Üzümlü, Bayırbağ and Pişkidağ districts, grape production dominates agriculture production and the famous 'Karaerik' grape cultivar has been cultivated for a long time on the very special traditional 'Baran' training system to avoid cold damage that occurs in winter months. The cultivar is harvested between 1 September and 1 October according to altitude in the region. The cultivar is well known in Turkey and there is a great demand for this cultivar in Turkey due to its perfect berry characteristics. In this study, yield, marketable product, cluster weight, cluster form, organic acids, specific sugars and sensory characteristics of the 'Karaerik' grape cultivar grown in three altitudes (1200 m a.s.l., $1400 \mathrm{~m}$ a.s.l. and $1600 \mathrm{~m}$ a.s.l., respectively) in Üzümlü district were investigated. For each altitude, grape clusters were sampled from ten vineyards and an average sample was formed. Marketable product, cluster weight, cluster form, organic acids and specific sugars were determined on those samples. Yield was determined as per decare. Sensory characteristics of samples were determined by five expert panelists. Results showed that the cluster weight was the highest in lower altitude and increasing altitude formed a more conical cluster form compared to winged cylindrical clusters at lower altitudes. The highest yield (740 kg per decare) was obtained in $1200 \mathrm{~m}$ a.s.l. and was followed by $1400 \mathrm{~m}$ a.s.l. (682 kg per decare) and $1600 \mathrm{~m}$ a.s.l. (724 kg per decare), respectively. Altitude strongly affected sugar and organic acid composition and ratio in berries of the 'Karaerik' grape. Fructose and tartaric acid were the main sugar and organic acid at all altitudes and were found between 10.04-14.02 g/100 $\mathrm{g}$ and 2.17-3.66 g/100 g, respectively. Sensory scores were also the highest at lower altitudes and decreased parallel to altitude increase.

Keywords: grape; altitude; sustainability; quality

\section{Introduction}

The Eastern Anatolia region is one of the most important regions in terms of floristic richness. Erzincan province, which has a transition feature between the East Black sea, Eastern Anatolia and Central Anatolia geographical regions, is well known as one of the most important plant gene and endemism centers in Turkey [1].

Flora of Turkey and East Aegean Islands [2] reported that Erzincan flora have 795 plant species belonging to 87 families and 342 genera. Of these, 276 species are endemic and a recent study indicated that the number of endemic plant species increased from 276 to 437 [3]. In addition, Erzincan is among Turkey's 13 endemic plant centers and 6 important plant areas in terms of plant richness [1]. Erzincan province has many microclimatic areas that show different habitats and encourage plant diversity. Erzincan is also a crossing point of Europe-Siberia and Iran-Turan phytogeographical regions and the Anatolian Diagonal. This situation causes the Erzincan region to host many endemic plant species [4]. 
The Erzincan region has immense potential for fruit crops due to favorable climate and soil conditions. A large number of horticultural crops including fruits (apples, pears, peaches, apricots, plums, mulberries, walnuts, almonds, cornelian cherries, sweet and sour cherries, etc.) have been growing at commercial scale in Erzincan plain and there are some fruit processing facilities in the region as well. The region also has huge potential in particular for field-grown high-quality tomatoes. The northern areas of Erzincan, including the Üzümlü, Bayırbağ and Pişkidağ districts, are very famous for their economic 'Karaerik' grape production. 'Karaerik' grape cultivar is recognized throughout the country due to its perfect table berry characteristics (unique aroma, better sugar/acidity ratio, attractive bigger dark purple berries, medium-thick peel and suitability for long storage). The cultivar entered the 'Registered Geographic Indications' list of the Turkish Patent Institute as the Cimin Grape on 13 June 2001 with the registration number 37. From this aspect, 'Karaerik' or 'Cimin' grape gained countrywide and global recognition and brand value while making contributions to the publicity of Erzincan at the same time. It is the first patented national grape cultivar in Turkey [5].

In fact, this cultivar is very well adapted to the Erzincan region and trials in the other grape-growing regions with this cultivar yielded negative results. The northern slopes of Erzincan which are completely covered by 'Karaerik' vineyards take light snow, so-called film snow layer (undamaged snow for grapes) and thus make the grape quality perfect. In Erzincan plain, around 4.000-4.500 tons of grapes are being produced annually and the majority of production is marketed within and in the surrounding areas of the region and a considerable income is generated due to high market price. Improving the production and market conditions of 'Karaerik' grape which is being demanded heavily from out of the province will make a contribution to increasing the income of the local community.

In the region, the farmers use, in general, environmentally friendly conventional grape production on the traditional 'Baran' training system. Winter cold damages often occur on the vineyards in the region. For this reason, farmers have developed the traditional 'Baran' system. The 'Baran' system consists of briefly covering the soil on the grapevine during the winter months to protect them from cold. In addition, the snow falling on the 'Baran' system in winter plays a cold-protective role. One of the most important disadvantages of the 'Baran' system is that the grape bunches come into contact with the soil and fungal infections appear. In order to prevent this, the use of mulch in vineyards has become widespread in recent years [6].

In the 'Baran' system, farmers produce very special 'Karaerik' table grapes and sell them with the highest price in Turkey. Farmers in general care much for the environment and recognize the importance of healthy soil for successful grape production. In conventional viticulture, they use both synthetic and naturally derived soil amendments, nutrients and pesticides. They also recently began using practices such as cover cropping and compost additions to obtain healthier grapes.

Grapes are one of the most produced fruit crops in the world in terms of total value of production (79 million metric tons) after bananas (117 million metric tons) and apples (87 million metric tons). Turkey is the sixth highest grape-producing country, with 4 million tons annual production and it shared $5 \%$ in world total production, after China (17\%), Italy (11\%), USA (9\%), Spain (8\%) and France (8\%) [7].

In Turkey, approximately 4.000 thousand tons of grapes are produced from 525 thousand hectares of vineyard areas. Approximately $30 \%$ of total production is used as fresh, $37 \%$ is dried, $30 \%$ is processed into molasses, cider, etc. and $5 \%$ is used for wine production. Around $27 \%$ of grape production of Turkey consists of seedless grapes. Seedless raisins are common in the Aegean region and table and wine grapes are common in the Marmara and Mediterranean region [6-10].

In the present study, we aimed to compare the performances of 'Karaerik' grape cultivar across three growing areas with different altitudes in the Erzincan condition, to determine the relative importance of environmental variation on their yield and morphological and biochemical properties. 


\section{Materials and Methods}

\subsection{Plant Material, Sampling and Location}

The clusters belonging to 'Karaerik' cultivar were harvested from vineyards located in Üzümlü district at three different altitudes (1200, 1400 and 1600 m a.s.l., respectively) in the 2019 growing season. The sampling vineyards are 15 years old and are established with the traditional 'Baran' training system. Ten grapevines from cv. 'Karaerik' were used per altitude. The clusters were harvested at the commercial harvest period at three altitudes. Harvested clusters were quickly brought to the laboratory. The berry samples were obtained homogenously from clusters and their laboratory analyses were conducted after the morphological measurements. The juices of the berries belonging to cv. 'Karaerik' were squeezed with a blender and the juices were obtained. The yield was determined as $\mathrm{kg} /$ decare.

\subsection{Traditional 'Baran' Training System}

The illustration of the traditional 'Baran' training system is given in Figure 1. This system has been used for a long time in Erzincan plain to avoid winter cold damages in vineyards. In this traditional system, raised beds with sandy gravel soils of $100 \mathrm{~cm}$ height and $100 \mathrm{~cm}$ width are made and two rows planting (the distance between two grapevines is $200 \mathrm{~cm}$ ) is applied. This system is called 'Baran' (Figure 2). The trunk of the grapevines is covered by soil around 90 percentages in winter months to avoid winter cold damage. The snow also covers top soils of 'Baran' in winter months and acts as insulation against cold. Between two 'Baran', 80-100 cm gap is left for furrow irrigation. 'Baran' are covered by plastic mulch in some vineyards recently (Figure 3). The first irrigation starts on 15 June and continues for 15-day intervals and finishes on 15 August. The technique allows the growth of grapes in Erzincan plain where the trellis wire system has been found to be unsuccessful against cold damage. In the 'Baran' system, grapevines face minimum water logging stress as plants are grown on ridges and furrows act as drainage lines for excess water. This method also saves water and increases quality and yield. The raised bed cultivation for grapevines in the region is found to be very suitable and sustainable for harvesting high-value 'Karaerik' grapes. The long period of observation indicates that the raised bed technique is a better option for grapevines in the region. In the region, 'Baran' are formed on the slopes against frost. Since the bottom buds of the 'Karaerik' grape variety are more productive, short pruning is performed on the grapevine. In pruning, one-year-old branches are pruned over three buds. About 20-25 buds are left on one grapevine (Figure 4). Since the soils of the region are sandy, there are no phylloxera pests. Vineyards at an altitude of 1200 were established in areas that have $5-10 \%$ slope. However, higher altitude vineyards were established in areas that have $15-20 \%$ slope.

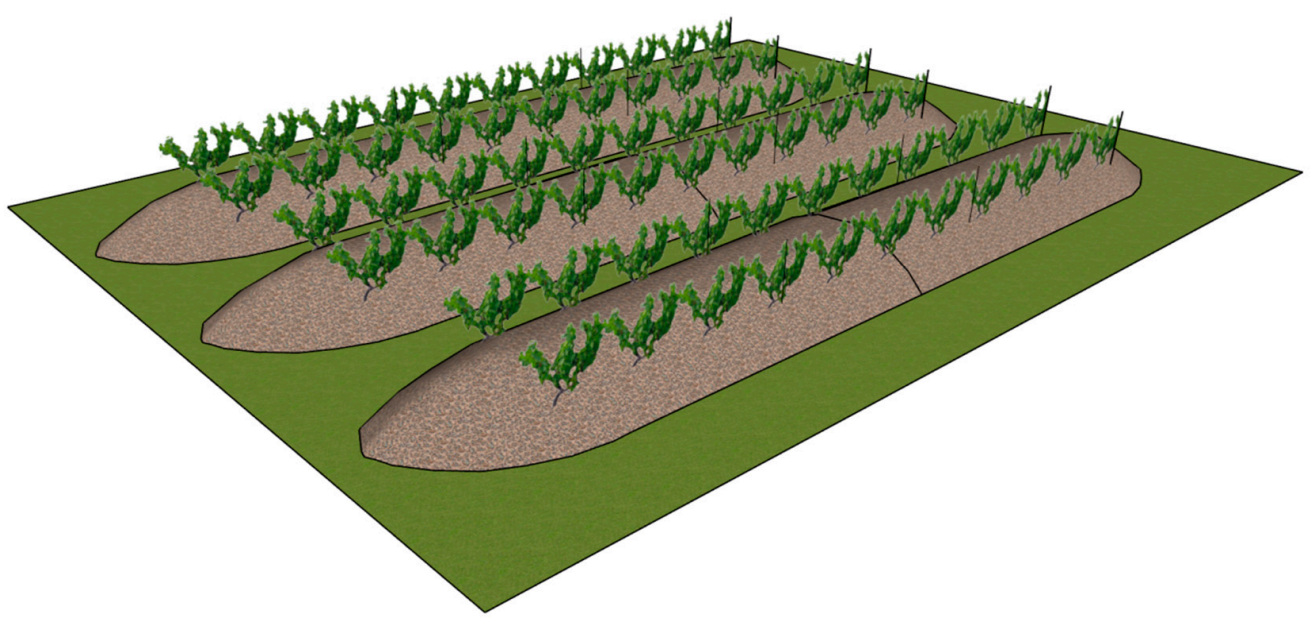

Figure 1. Illustration of traditional 'Baran' training system. 

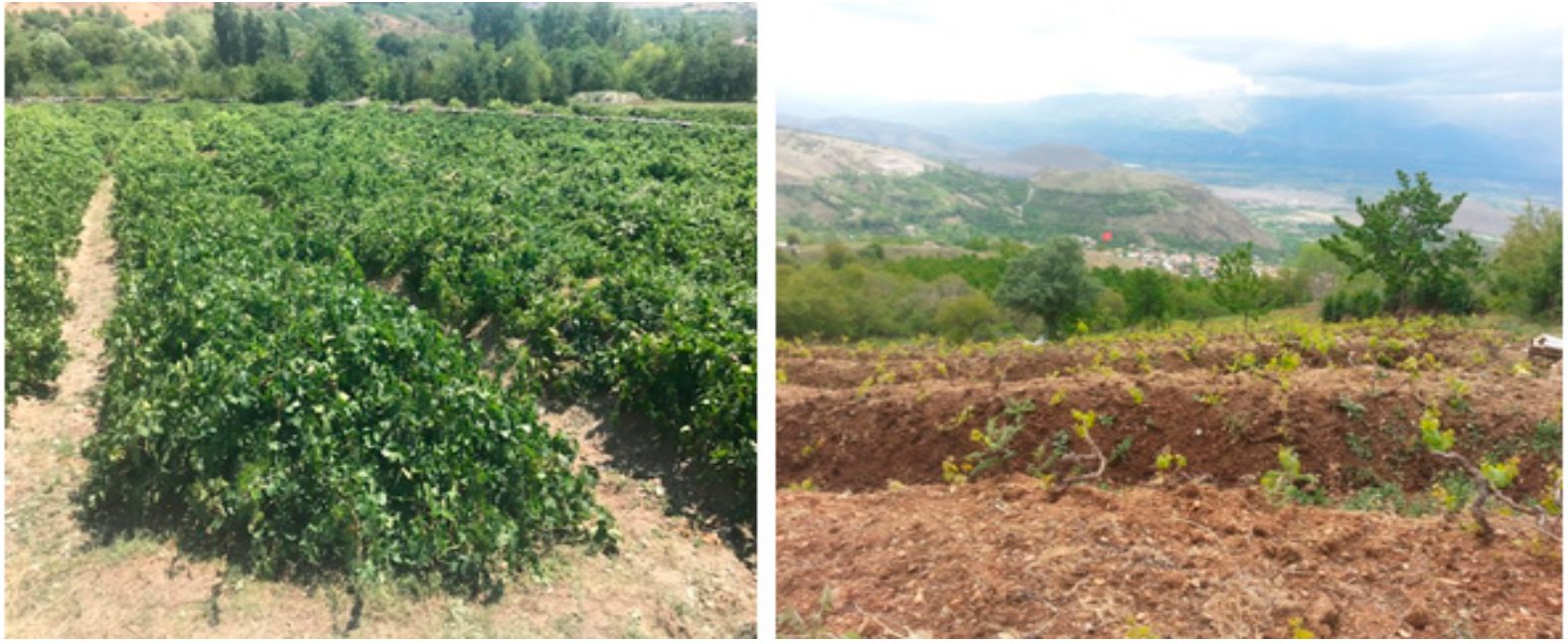

Figure 2. The vineyards in traditional 'Baran' training system in Üzümlü district.

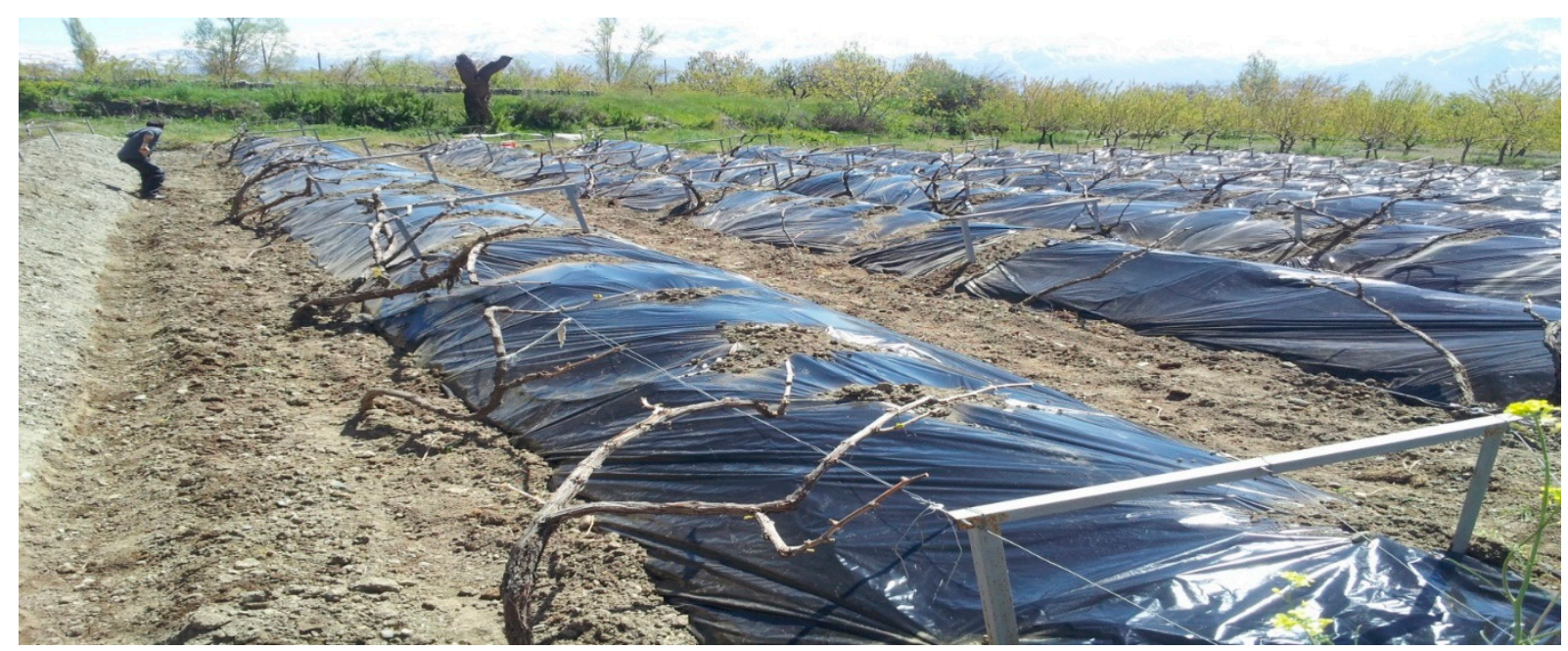

Figure 3. The 'Baran' training system covered by plastic mulch.
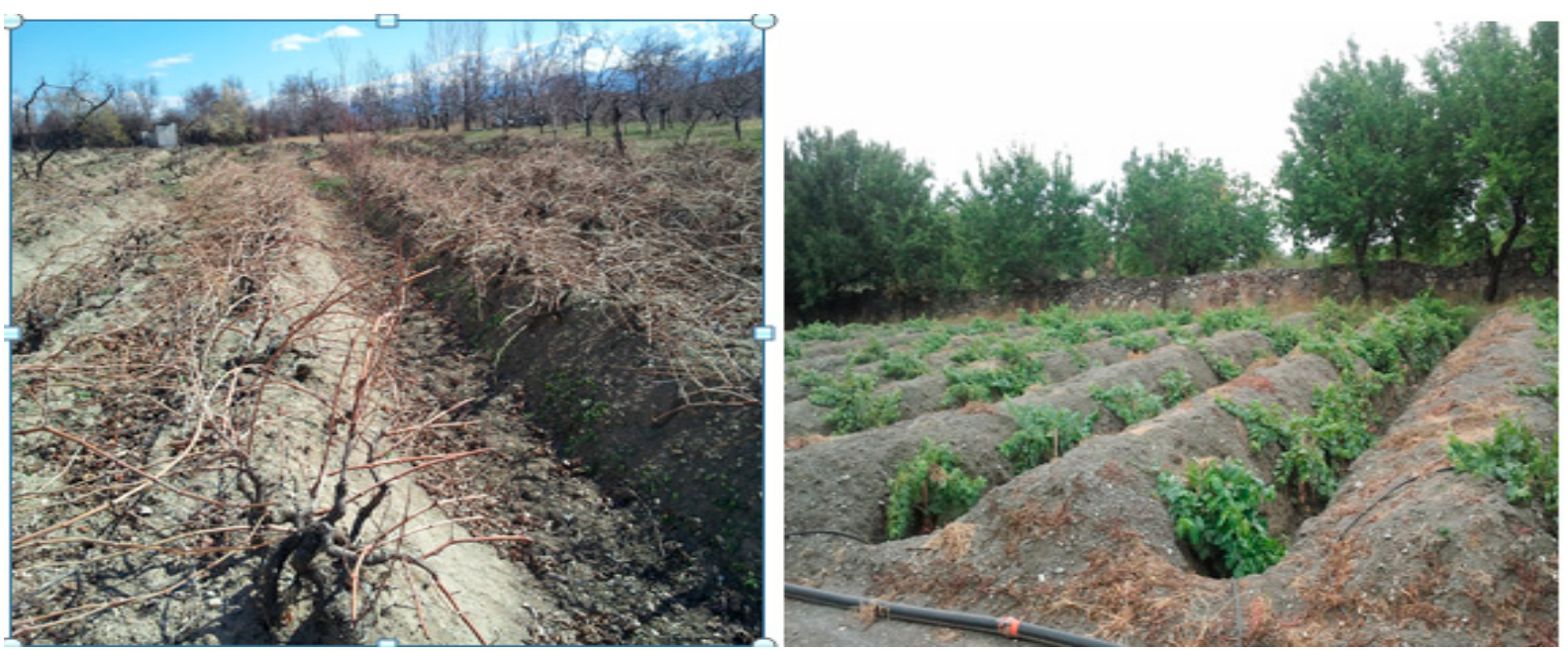

Figure 4. Grapevines during dormancy and vegetation stages on 'Baran' training system. 


\subsection{Morphological Traits}

Cluster weight and cluster form were performed in the full ripening period, in a representative 10 clusters per grapevine [11,12].

\subsection{Biochemical Traits}

\subsubsection{Specific Sugars}

Sugar (fructose, sucrose and glucose) analysis was performed with the methods described by Melgarejo et al. [13]. First, $1 \mathrm{~mL}$ of fruit extract was centrifuged at 10,000 rev per min for $2 \mathrm{~min}$ at $4{ }^{\circ} \mathrm{C}$. Supernatants were passed by SEP-PAK C18 cartridge. HPLC readings were made with $\mu$ bondapak- $\mathrm{NH}_{2}$ column using $85 \%$ acetonitrile as the liquid phase with a refractive index detector (IR). Fructose and glucose standards were used for the calculations of the sugar contents. Results were expressed as $\mathrm{g} / 100 \mathrm{~g}$ fresh weight base.

\subsubsection{Organic Acids}

Organic acid composition of the berries was determined as described by Bevilacqua and Califano [14]. Berry extracts were obtained by crushing the berries in cheesecloth Then, $0.009 \mathrm{~N} \mathrm{H}_{2} \mathrm{SO}_{4}$ was homogenized with a shaker for $1 \mathrm{~h}$. The mixture was then centrifuged at 15,000 rpm for $15 \mathrm{~min}$ and the supernatants were filtered twice through a $0.45 \mu \mathrm{m}$ membrane filter with a coarse filter (Millipore Millex-HV Hydrophilic PVDF, Millipore, Burlington, MA, USA) and passed through a SEP-PAK C18 cartridge. Organic acid readings were performed by HPLC using the Aminex column (HPX-87 H, $300 \mathrm{~mm} \times 7.8 \mathrm{~mm}$, Bio-Rad Laboratories, Richmond, CA, USA) at 214 and $280 \mathrm{~nm}$ wavelengths in the Agilent package program (Agilent Technologies, Inc, Santa Clara, CA, USA). Results were expressed as $\mathrm{g} / 100 \mathrm{~g}$ fresh weight base.

\subsection{Sensory Evaluation}

For sensory properties, a panel including five experts established and evaluated the 'Karaerik' grape's sensory characteristics. Five panelists tasted the samples and completed a short questionnaire covering the quality indicators independently. Sensory attributes of the table grape consist of appearance (color), cleanliness (berry bloom), taste and texture. In this study we used the 9-point hedonic scale based on previous research [15] for the evaluation experiment. According to score criterion, 1 means dislike extremely; $2=$ dislike very much; $3=$ dislike moderately; $4=$ dislike slightly; $5=$ neither like nor dislike; $6=$ like slightly; 7 = like moderately; $8=$ like very much; 9 = like extremely.

\subsection{Statistical Analysis}

The study was planned as four replications, including 10 clusters per replicate. In the statistical evaluations, Windows SPSS 20 was used and the differences between the means were evaluated by subjecting them to ANOVA variance analysis and were determined with Duncan multiple comparison test $(p<0.05)$.

\section{Results and Discussion}

\subsection{Yield, Marketable Product and Morphological Traits}

Table 1 presents average yield, marketable product and some important morphological traits of 'Karaerik' grape samples grown at three different altitudes of Üzümlü district. 
Table 1. Yield, marketable product and some morphological traits of 'Karaerik' grape samples.

\begin{tabular}{cccccc}
\hline Altitude & $\begin{array}{c}\text { Yield } \\
\text { (kg/Decare) }\end{array}$ & $\begin{array}{c}\text { Marketable } \\
\text { Product (\%) }\end{array}$ & Harvest Period & Cluster Form & Cluster Weight (g) \\
\hline 1200 m a.s.l. & $740 \mathrm{a}$ & $86.40 \mathrm{a}$ & Mid-season & Winged cylindrical & $478 \mathrm{a}$ \\
$1400 \mathrm{~m}$ a.s.l. & $682 \mathrm{~b}$ & $79.12 \mathrm{~b}$ & Mid-late season & Winged conical & $430 \mathrm{~b}$ \\
1600 m a.s.l. & $624 \mathrm{c}$ & $78.33 \mathrm{~b}$ & Late season & Conical & $390 \mathrm{c}$ \\
\hline
\end{tabular}

Mid-season: 1 September-1 October; mid-late: 10 September-10 October; late season: 15 September-15 October. The 'Karaerik' samples at different altitudes compared in the same columns and different letters show statistically significant differences $(p<0.05)$.

Yield, marketable product and cluster weight varied by location and showed significant differences $(p<0.05)$ (Table 1$)$. The harvest season was also varied among samples according to 1200,1400 and $1600 \mathrm{~m}$ a.s.l.

The highest yield (740 kg per decare) was obtained from 'Karaerik' grape samples at $1200 \mathrm{~m}$ a.s.l. and was followed by $1400 \mathrm{~m}$ a.s.l. (682 $\mathrm{kg} / \mathrm{daa})$ and $1600 \mathrm{~m}$ a.s.l. (624 kg/decare). It is obvious that altitude increase decreased yield per da in 'Karaerik' grape cultivar in Üzümlü conditions. Reference [16] reported higher yield per decare in Sultani Seedless grape cultivars in Tokat conditions as $1029-1849 \mathrm{~kg} /$ decare. Ates and Uysal [17] reported that grape yield per decare changes in Turkey according to grapegrowing regions and found between 562 and $820 \mathrm{~kg} /$ decare. In Turkey, according to grape-growing regions, the average yield per decare was 900-950 kg [18]. Gazioglu Sensoy and Balta [19] found yield per da between 679 and $950 \mathrm{~kg}$ in cv. Hamburg Misketi in Eastern Anatolia conditions.

The marketable product ratio was the highest in $1200 \mathrm{~m}$ a.s.l. at $86.40 \%$ while it was the lowest in the higher altitude $(1600 \mathrm{~m}$, a.s.l.) at $78.33 \%$. Statistically, there were no differences for marketable product between 1400 and $1600 \mathrm{~m}$, a.s.l. $(p<0.05)$. However, $1200 \mathrm{~m}$, a.s.l. exhibited significant differences from 1400 and $1600 \mathrm{~m}$, a.s.l. (Table 1).

In terms of harvest season, 'Karaerik' grapes were harvested in mid-season at $1200 \mathrm{~m}$ a.s.l., mid-late season at $1400 \mathrm{~m}$ a.s.l. and late season at $1600 \mathrm{~m}$ a.s.l. (Table 1).

According to altitudes, cluster form differed and at $1200 \mathrm{~m}$ a.s.l., 'Karaerik' cultivar produced winged cylindrical cluster form, at $1400 \mathrm{~m}$ a.s.l., it was winged conical and at the highest altitude (1600 m a.s.l.) it was conical form (Table 1, Figure 5). Average cluster weight of the 'Karaerik' cultivar was found to be the lowest, $390 \mathrm{~g}$, at $1600 \mathrm{~m}$ a.s.l., followed by $430 \mathrm{~g}$ at $1400 \mathrm{~m}$ a.s.l. and the highest value was obtained from $1200 \mathrm{~m}$ a.s.l. as $478 \mathrm{~g}$, respectively. According to OIV [20], cluster weight at all altitudes was found to be over $300 \mathrm{~g}$ and this was classified as big. In grapes, cluster weight is strongly affected by cultivar, altitude, cluster thinnings, etc. Kok et al. [21] reported cluster weight in grape cultivars between 232 and $560 \mathrm{~g}$, which indicated good agreement with our results. Dilli and Kader [22] studied table grape cultivars widely grown in Turkey and reported that the cultivars were harvested early, mid and late period. They also found that common table cultivars had big cluster weight. Uniform color formation, pleasing flavor and texture, medium size of cluster, large uniform berries and suitability for transportation are desirable traits for table grapes [23,24]. 

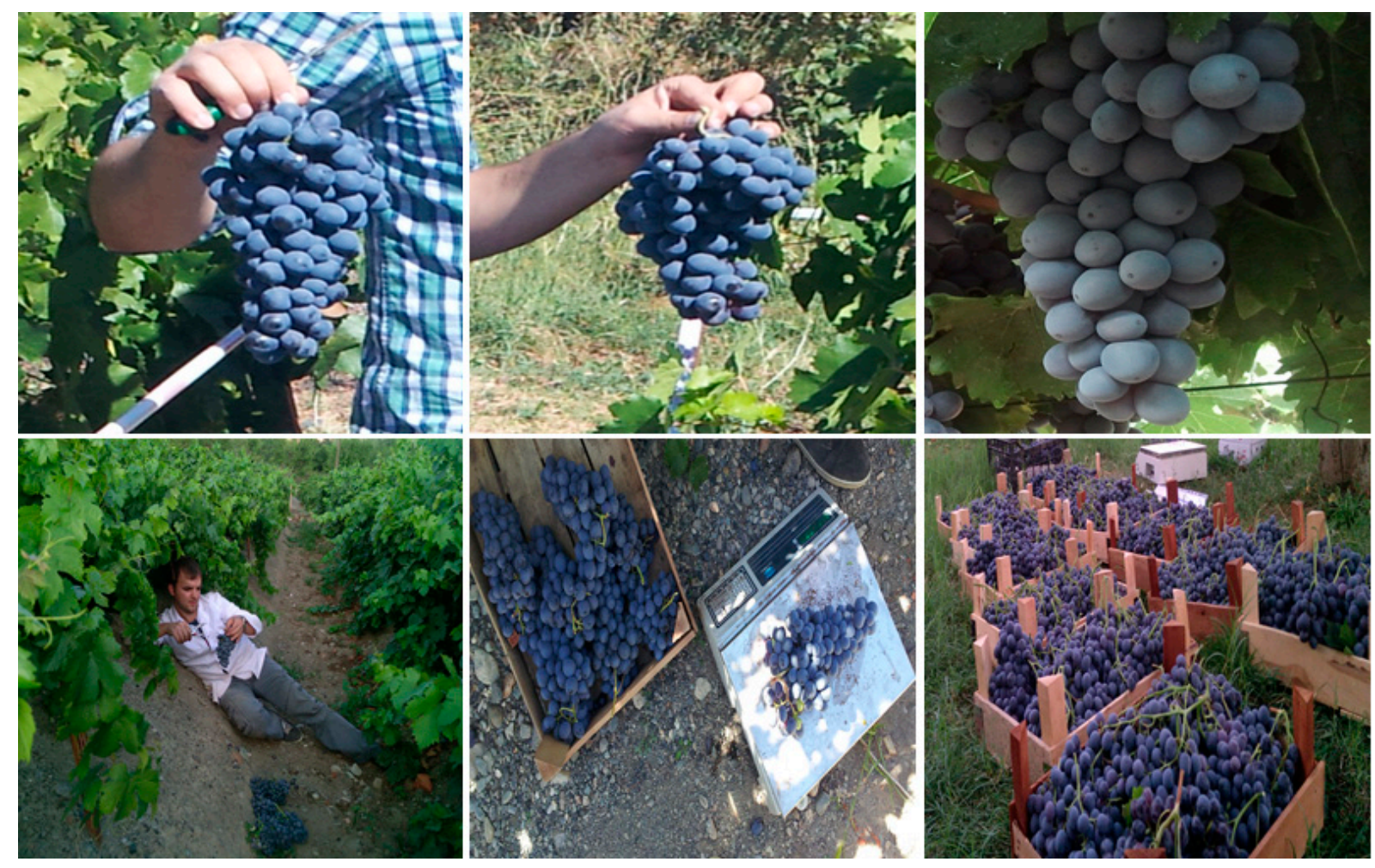

Figure 5. Different cluster form of cv. 'Karaerik' at harvest on 'Baran' training system.

\subsection{Sugar Content}

The sugar content in berries of cv. 'Karaerik' at 1200, 1400 and $1600 \mathrm{~m}$, a.s.l. is given in Table 2. There were statistically significant differences $(p<0.05)$ among berries belonging to cv. 'Karaerik' grown at different altitudes. As shown in Table 2, fructose was the most abundant sugar and the concentration of fructose in berries of cv. 'Karaerik' was the highest (14.02 g/100 g FW) at the highest altitude ( $1600 \mathrm{~m}$, a.s.l.), followed by $11.63 \mathrm{~g} / 100 \mathrm{~g}$ FW (1400 m, a.s.l.) and $10.04 \mathrm{~g} / 100 \mathrm{~g}$ FW (1200 m, a.s.l.), respectively. Glucose values were found to be closer to fructose and varied from $8.94 \mathrm{~g} / 100 \mathrm{~g} \mathrm{FW}(1200 \mathrm{~m}$, a.s.l.) to $11.84 \mathrm{~g} / 100 \mathrm{~g}$ FW (1600 m, a.s.l.), respectively. The sucrose content was found to be a negligible amount and fluctuated between 0.05 and $0.09 \mathrm{~g} / 100 \mathrm{~g}$ FW (Table 2). Previous studies indicated that fructose and glucose content and ratio greatly changed according to grape cultivar, growing conditions, cultural treatments, etc. [25,26]. Zhang et al. [27] showed that among the five varieties of table grapes grown in China, fructose content is slightly higher than glucose and both sugars, accounting for $96.00-98.00 \%$ of the total sugar contents in grape berries. Studies also indicate that main sugars of grape berries are fructose and glucose and their ratio was found to be much closer to each other in grape cultivars [28,29]. Sensoy et al. [30] and Eyduran et al. [25] showed that glucose and fructose content are close to each other in grape cultivars. Petrisor and Chirecanu [26] reported that sucrose content was very low, even non-detectable, in all grape cultivars and they found the ratio of glucose/fructose in berries of grape cultivars varied in range from 1.0 to 1.06. They also found that some cultivars had slightly higher fructose content than glucose. Glucose and fructose are the main sugars in grape berries [31,32], indicating similarities with our results. The content of sucrose in grape was low in our samples. Previously, sucrose was found to be low in grape berries [33-36]. Grape color, flavor and nutritional composition are strongly influenced by sugar content, and sugar is also one of the important signs showing the ripeness of grapes $[4,5]$. 
Table 2. Sugar content (g/100 g FW) of 'Karaerik' grape samples at different altitudes.

\begin{tabular}{cccc}
\hline Sample Altitude & Fructose & Glucose & Sucrose \\
\hline $1200 \mathrm{~m}$ a.s.l. & $10.04 \mathrm{c}$ & $8.94 \mathrm{c}$ & $0.09 \mathrm{NS}$ \\
$1400 \mathrm{~m}$ a.s.l. & $11.63 \mathrm{~b}$ & $10.60 \mathrm{~b}$ & 0.08 \\
$1600 \mathrm{~m}$ a.s.l. & $14.02 \mathrm{a}$ & $11.84 \mathrm{a}$ & 0.05 \\
\hline
\end{tabular}

The 'Karaerik' samples at different altitudes compared in the same columns and different letters show statistically significant differences $(p<0.05)$. NS: Non significant.

\subsection{Organic Acid Content}

The results obtained for organic acids in berries of cv. 'Karaerik' at three different altitudes are given in Table 3. There were statistically significant differences $(p<0.05)$ among berries belonging to cv. 'Karaerik' grown at different altitudes for tartaric and malic acid content (Table 3 ).

Table 3. Organic acid content (g/100 g FW) of 'Karaerik' grape samples at different altitudes.

\begin{tabular}{cccc}
\hline Sample Altitude & Tartaric & Malic & Citric \\
\hline 1200 m a.s.l. & $2.17 \mathrm{c}$ & $1.45 \mathrm{c}$ & $0.14^{\mathrm{NS}}$ \\
$1400 \mathrm{~m}$ a.s.l. & $2.88 \mathrm{~b}$ & $1.84 \mathrm{~b}$ & 0.22 \\
$1600 \mathrm{~m}$ a.s.l. & $3.66 \mathrm{a}$ & $2.30 \mathrm{a}$ & 0.25 \\
\hline
\end{tabular}

The 'Karaerik' samples at different altitudes compared in the same columns and different letters show statistically significant differences $(p<0.05)$. NS: Non significant.

As indicated in Table 3, the main organic acid was tartaric acid in berries of cv. 'Karaerik' and it changed from $2.17 \mathrm{~g} / 100 \mathrm{~g}$ FW at $1200 \mathrm{~m}$ a.s.l. to $3.66 \mathrm{~g} / 100 \mathrm{~g}$ FW at $1600 \mathrm{~m}$ a.s.l., respectively. Next to tartaric acid, malic acid was in the range of $1.45 \mathrm{~g} / 100 \mathrm{~g}$ FW (1200 $\mathrm{m}$ a.s.1.) and $2.30 \mathrm{~g} / 100 \mathrm{~g}$ (1600 $\mathrm{m}$ a.s.l.), indicating that higher altitudes accumulated more malic acid, as shown in tartaric acid. The citric acid content was found to be a negligible amount and fluctuated between 0.14 and $0.25 \mathrm{~g} / 100 \mathrm{~g}$ FW in berries of cv. 'Karaerik' (Table 3).

Previous studies also indicated that tartaric acid and malic acid were the main organic acids in grape berries, accounting for $55-60 \%$ and $30-39 \%$ of the total organic acids, respectively [25-27]. In Brazil, Couelho et al. [37] found that tartaric acid was the main organic acid present in grape juices, representing over $50 \%$ of the total acids quantified. Zhang et al. [27] showed that among the five varieties of table grapes grown in China, tartaric acid and malic acid were the main organic acids. Organic acids are the major metabolites existing in grapes whose compositions and concentrations are the essential parameters related to grape processing and quality evaluation $[38,39]$. The organic acid content can directly affect the taste balance, chemical stability and $\mathrm{pH}$ value of grape berries.

\subsection{Sensory Evaluation}

Grape cultivars have diverse color, taste, cleanliness and texture characteristics that affect consumers because consumers have a high degree of sensitivity and can distinguish color, taste, cleanliness and texture characteristics which all form the sensory properties of grape berries.

Sensory appearance score of cv. 'Karaerik' berries was the highest at $1200 \mathrm{~m}$ a.s.l. and was lower at 1400 and $1600 \mathrm{~m}$, a.s.l. (Table 4). The cultivar had uniform blackish-purple color at all altitudes. High altitude encouraged cleanliness which is a vital parameter for 'Karaerik' grape cultivar because farmers do not touch berries during harvest to avoid berry bloom. The consumers highly appreciated berry bloom and accepted it as quality criterion. In 'Karaerik' cultivar at all altitudes, bloom was evenly and fully distributed, dry and clean. Taste was the highest at lower altitude and the cultivar had a pleasant sweet-sour ratio at all altitudes. The highest altitudes gave more firm 'Karaerik' grape berries (Table 4). 
Table 4. Sensory characteristics of 'Karaerik' grapes at three different altitudes.

\begin{tabular}{ccccc}
\hline $\begin{array}{c}\text { Sample } \\
\text { Altitude }\end{array}$ & $\begin{array}{c}\text { Appearance } \\
\text { (Color) }\end{array}$ & $\begin{array}{c}\text { Cleanliness } \\
\text { (Berry Bloom) }\end{array}$ & Taste & Texture \\
\hline 1200 m a.s.l. & $8.60 \mathrm{a}$ & $8.20 \mathrm{~b}$ & $8.00 \mathrm{a}$ & $7.60 \mathrm{~b}$ \\
1400 m a.s.l. & $8.20 \mathrm{~b}$ & $8.00 \mathrm{~b}$ & $7.60 \mathrm{~b}$ & $8.00 \mathrm{a}$ \\
$1600 \mathrm{~m}$ a.s.l. & $7.80 \mathrm{c}$ & $8.60 \mathrm{a}$ & $7.60 \mathrm{~b}$ & $8.00 \mathrm{a}$ \\
\hline
\end{tabular}

1 means dislike extremely; 2 = dislike very much; 3 = dislike moderately; 4 = dislike slightly; 5 = neither like nor dislike; $6=$ like slightly; 7 = like moderately; $8=$ like very much; $9=$ like extremely. The 'Karaerik' samples at different altitudes compared in the same columns and different letters show statistically significant differences $(p<0.05)$.

Some grape cultivars had berry surface bloom, a thin layer of wax-like material coating the outer surface of the berry [36-40] and it is accepted as one of the important quality criteria like berry shape and color. However, berry bloom always gives the consumers the wrong impression that the berry has been lightly and uniformly dusted or frosted.

Appearance is one of the major factors for assessing quality of horticulture crops, including fruits and vegetables [41-50]. Pale green, light yellow, pink, red, purple and black are common peel and flesh colors of grape berries. Another quality criterion is taste, which is attributed to the sensory quality of grape berries. Grape berries are more attractive to consumers if the grape berries have intense perfume and plump, juicy, sweet and sour flesh $[51,52]$.

\section{Conclusions}

The results of this study show that the traditional 'Baran' training system allows local grape growers to sustain viticultural production in Erzincan plain at different altitudes from 1100 to $1700 \mathrm{~m}$ a.s.l. In literature, very few studies have assessed yield, morphology, organic acid and sugar content of grapes grown in different altitudes. The 'Karaerik' grape cultivar studied here presented considerable variation with reference to yield, morphological traits, major sugars, organic acids and sensory characteristics at different altitudes. The cluster form changed according to altitude and higher altitude gave more conical clusters. The highest tartaric acid was observed at the highest altitude (1600 $\mathrm{m}$ a.s.l.). Taste was the highest at lower altitude and the cultivar has a pleasant sweet-sour ratio at all altitudes. The highest altitudes gave more firm 'Karaerik' grape berries.

Author Contributions: Conceptualization, M.K. and S.E.; data curation, S.E. and M.K.; formal analysis, S.E. and M.K.; methodology, S.E. and M.K.; project administration, M.K. and S.E.; visualization, M.K., M.B. and J.S.; writing—original draft, S.E., M.B. and J.S.; writing—review and editing, S.E., M.B. and J.S. All authors have read and agreed to the published version of the manuscript.

Funding: This study was supported by the project CZ.02.1.01/0.0/0.0/16_017/0002334 Research Infrastructure for Young Scientists; this is co-financed by Operational Programme Research, Development and Education.

Institutional Review Board Statement: Not applicable.

Informed Consent Statement: Not applicable.

Data Availability Statement: All-new research data were presented in this contribution.

Conflicts of Interest: The authors declare that they have no conflict of interest.

\section{References}

1. Kandemir, A. Endemic plants of Erzincan and threatening. In Proceedings of the Biological Diversity Symposium, Ankara, Turkey, 22-23 May 2012; pp. 108-109.

2. Davis, P.H. (Ed.) 1965-1985. Flora of Turkey and the East Aegean Islands; Edinburgh Univ. Press: Edinburgh, UK, 2000; Volume 1-9.

3. Korkmaz, M.; Ozcelik, H.; Kandemir, A.; Ilhan, V. Natural rose (Rosa L.) taxa distributed in Erzincan and its Envrons. Suleyman Demirel Univ. J. Nat. Appl. Sci. 2013, 17, 49-59.

4. Ozhatay, N. Important Plant Areas around BTC Pipeline; BTC Company: Istanbul, Turkey, 2006; pp. 125-127. 
5. Akpinar, E.; Celikoglu, S. The contribution of Cimin (black plum) grape to the economy and publicity of Erzincan. In Proceedings of the International Erzincan Symposium, Erzincan, Turkey, 28 September-1 October 2016; Volume 2, pp. 16-23.

6. Kupe, M. Determining Suitable Pruning Level after Winter Frost Damage in Karaerik Grape Cultivar Grown in Uzumlu District of Erzincan. Master's Thesis, Ataturk University Institute of Science, Erzurum, Turkey, 2013; 75p.

7. FAO. Food and Agriculture Organization of the United Nations. 2020. Available online: http://www.fao.org/faostat/en/\#data/ QC (accessed on 12 June 2021).

8. Çelik, H.; Köse, B.; Cangi, R. Determination of Fox grape genotypes (Vitis labrusca L.) grown in Northeastern Anatolia. Hort. Sci. 2008, 35, 162-170.

9. Soylemezoglu, G.; Atak, A.; Boz, Y.; Unal, A.; Saglam, M. Viticulture in Turkey. Chronica Hortic. 2016, 56, 27-31.

10. Isci, B.; Kacar, E.; Altındisli, A. The effects of some exogenous applications on quality in 'Crimson Seedless' grape. Erwerbs-Obstbau 2020, 62, 87-100. [CrossRef]

11. Kara, Z.; Yazar, K.; Doğan, O.; Vergili, E. Sodium nitroprusside and gibberellin effects on seed germination and seedling development of grapevine (Vitis vinifera L.) cvs. Ekşi Kara and Gök Üzüm. Erwerbs-Obstbau 2020, 62, 61-68. [CrossRef]

12. Tangolar, S.; Tangolar, S.; Turan, M.; Ateş, F. Determination of phytochemical and mineral contents of seeds from 'Semillon'and 'Carignane' wine grape cultivars grown under different irrigation conditions. Erwerbs-Obstbau 2020, 62, 115-123. [CrossRef]

13. Melgarejo, P.; Salazar, D.M.; Artes, F. Organic acids and sugars composition of harvested pomegranate fruits. Eur. Food Res. Technol. 2000, 211, 185-190. [CrossRef]

14. Bevilacqua, A.E.; Califano, A.N. Determination of organic acids in dairy products by high performance liquid chromatography. $J$. Food Sci. 1989, 54, 1076-1079. [CrossRef]

15. Chouksey, S.; Singh, A.; Thakur, R.S.; Deshmukh, R. Influence of gamma irradiation and benzyl adenine on keeping quality of custard apple fruits during storage. J. Food Sci. Technol. 2013, 50, 934-941. [CrossRef]

16. Cangi, R.; Kesgin, M.; Yagci, A. An economic analysis of shading and covering material applications on table grape growing of sultani seedless cultivar. J. Agric. Fac. Gaziosmanpaşa Univ. 2011, 28, 9-19.

17. Ates, F.; Uysal, H. Determinations of adaptation level of wine grape varieties in terms of climatic data in wine growing regions of turkey. BIO Web Conf. 2017, 9, 01027. [CrossRef]

18. TURKSTAT. Turkish Statistical Institute Online Statistical Database: Turkish Statistical Institute. 2019. Available online: https: / / biruni.tuik.gov.tr (accessed on 10 October 2020).

19. Gazioglu Sensoy, R.I.; Balta, F. Adaptation of some grape cultivars to Van ecological condition. YYU J. Agric. Sci. 2010, 20, 159-170.

20. OIV. Organisation Internationale de la Vigne et du Vin. In OIV Descriptor List for Grape Varieties and Vitis Species, 2nd ed.; Organization Intergouvernementale crée par l'Accord International: Paris, France, 2001; Available online: https://www.oiv.int/ public/medias /2274/ code-2e-edition-finale.pdf (accessed on 20 June 2021).

21. Kök, D.; Bal, E.; Bahar, E. Physical and biochemical traits of selected grape varieties cultivated in Tekirdağ, Turkey. Int. J. Sustain. Agric. Manag. Inform. 2017, 3, 215-223. [CrossRef]

22. Dilli, Y.; Kader, S. 2020; Table, Wine and Dried Grape Cultivars. Available online: https://arastirma.tarimorman.gov.tr/ manisabagcilik/Belgeler/genelbagcilik/UZUM\%20CESITLERI\%20YILDIZ\%20DILLI.pdf (accessed on 25 June 2021).

23. Winkler, A.J.; Cook, J.A.; Kliewer, W.M.; Lider, L.A. General Viticulture, 2nd ed.; University of California Press: Berkeley, CA, USA, $1974 ; 710 \mathrm{p}$.

24. Dardeniz, A. Effects of cluster tipping on yield and quality of Uslu and Cardinal table grape cultivars. COMU J. Agric. Fac. 2014, 2, 21-26.

25. Eyduran, S.P.; Akin, M.; Ercisli, S.; Eyduran, E.; Maghradze, D. Sugars, organic acids, and phenolic compounds of ancient grape cultivars (Vitis vinifera L.) from lgdir province of Eastern Turkey. Biol. Res. 2015, 48, 2. [CrossRef] [PubMed]

26. Petrisor, C.; Chirecanu, C. Organic acids and sugars profile of some grape cultivars affected by grapevine yellows symptoms. Rom. Biotechnol. Lett. 2019, 24, 1027-1033. [CrossRef]

27. Zhang, D.; Zhang, Y.; Lin, K.; Wang, B.; Shi, X.; Cheng, W. Comparison of sugars, organic acids and aroma components of five table grapes in Xinjiang. IOP Conf. Ser. Earth Environ. Sci. 2021, 792, 012029. [CrossRef]

28. Korkutal, I.; Bahar, E.; Ozge, K. The effect of altitude on grape quality. Trakya Univ. Eng. Sci. J. 2012, 13, 17-29.

29. Frioni, T.; Squeri, C.; Del Zozzo, F.; Guadagna, P.; Gatti, M.; Vercesi, A.; Poni, S. Investigating evolution and balance of grape sugars and organic acids in some new pathogen-resistant white grapevine varieties. Horticulturae 2021, 7, 229. [CrossRef]

30. Sensoy Gazioglu, R.I. Determination of organic acids, sugars, and macro-micro nutrient contents of must in some grape (Vitis vinifera L.) cultivars. J. Anim. Plant Sci. 2015, 25, 693-697.

31. Meng, J.-F.; Xu, T.-F.; Song, C.-Z.; Yu, Y.; Hu, F.; Zhang, L.; Zhang, Z.-W.; Xi, Z.-M. Melatonin treatment of pre-veraison grape berries to increase size and synchronicity of berries and modify wine aroma components. Food Chem. 2015, 185, 127-134. [CrossRef]

32. Davies, C. Sugar accumulation in grape berries. Cloning of two putative vacuolar invertase cDNAs and their expression in grapevine tissues. Plant Physiol. 1996, 111, 275-283. [CrossRef]

33. Xie, Z.; Li, B.; Forney, C.F.; Xu, W.; Wang, S. Changes in sugar content and relative enzyme activity in grape berry in response to root restriction. Sci. Hortic. 2009, 123, 39-45. [CrossRef] 
34. Zheng, L.; Nie, J.; Yan, Z. Advances in research on sugars, organic acids and their effects on taste of fruits. J. Fruit Sci. 2015, 32, 304-312.

35. Liu, F.; Wu, B.-H.; Fan, P.-G.; Li, S.-H.; Li, L.-S. Sugar and acid concentrations in 98 grape cultivars analyzed by principal component analysis. J. Sci. Food Agric. 2006, 86, 1526-1536. [CrossRef]

36. Piazzolla, F.; Pati, S.; Amodio, M.; Colelli, G. Effect of harvest time on table grape quality during on-vine storage. J. Sci. Food Agric. 2016, 96, 131-139. [CrossRef]

37. Coelho, E.M.; Padilha, C.V.S.; Miskinis, G.A.; de Sa, A.G.B.; Pereira, G.E.; Azavedo, L.C.; Lima, M.S. Simultaneous analysis of sugars and organic acids in wine and grape juices by HPLC: Method validation and characterization of products from northeast Brazil. J. Food Comp. Anal. 2018, 66, 160-167. [CrossRef]

38. Jediyi, H.; Naamani, K.; Elkoch, A.A.; Dihazi, A.; El Fels, E.A.; Arkize, W. First study on technological maturity and phenols composition during the ripeness of five Vitis vinifera L. grape varieties in Morocco. Sci. Hortic. 2019, 246, 390-397. [CrossRef]

39. Gokturk-Baydar, N. Organic acid, tocopherol and phenolic compositions of some Turkish grape cultivars. Chem. Nat. Compd. 2006, 42, 56-59. [CrossRef]

40. Webb, A.D. Quality factors in California grapes. In Quality of Selected Fruits and Vegetables of North America; Teranishi, R., Barrera-Benitez, H., Eds.; American Chemical Society: Washington, DC, USA, 1981; pp. 1-9.

41. Zia-Ul-Haq, M.; Ahmad, S.; Qayum, M.; Ercisli, S. Compositional studies and antioxidant potential of Albizia lebbeck (L.) Benth. Pods and seeds. Turk. J. Biol. 2013, 37, 25-32.

42. Bolat, I.; Dikilitas, M.; Ercisli, S.; Ikinci, A.; Tonkaz, T. The effect of water stress on some morphological, physiological, and biochemical characteristics and bud success on apple and quince rootstocks. Sci. World J. 2014, 2014, 1-8.

43. Dogan, H.; Ercisli, S.; Jurikova, T.; Temim, E.; Leto, A.; Hadziabulic, A.; Tosun, M.; Narmanlioglu, H.K.; Zia-Ul-Haq, M. Physicochemical and antioxidant characteristics of fruits of cape gooseberry (Physalis peruviana L.) from Turkey. Oxid. Commun. 2014, 37, 1005-1014.

44. Dogan, H.; Ercisli, S.; Temim, E.; Hadziabulic, A.; Tosun, M.; Yilmaz, S.O.; Zia-Ul-Haq, M. Diversity of chemical content and biological activity in flower buds of a wide number of wild grown caper (Capparis ovate Desf.) genotypes from Turkey. Comptes Rendus Acad. Bulg. Sci. 2014, 67, 1593-1600.

45. Gundogdu, M.; Ozrenk, K.; Ercisli, S.; Kan, T.; Kodad, O.; Hegedus, A. Organic acids, sugars, vitamin C content and some pomological characteristics of eleven hawthorn species (Crataegus spp.) from Turkey. Biol. Res. 2014, 47, 21. [CrossRef]

46. Candir, E.; Ozdemir, A.E.; Aksoy, M.C. Effects of modified atmosphere packaging on the storage and shelf life of Hicaznar pomegranate fruits. Turk. J. Agric. For. 2019, 43, 241-253. [CrossRef]

47. Ozdemir, A.E.; Didin, O.; Candir, E.; Kaplankiran, M.; Yildiz, E. Effects of rootstocks on storage performance of Nova mandarins. Turk. J. Agric. For. 2019, 43, 307-317. [CrossRef]

48. Ozkan, G. Phenolic compounds, organic acids, vitamin C and antioxidant capacity in Prunus spinose. Comptes Rendus Acad. Bulg. Sci. 2019, 72, 267-273.

49. Bozhuyuk, M.R.; Ercisli, S.; Orhan, E.; Koc, A. Determination of the genetic diversity of walnut (Juglans regia L.) cultivar candidates from Northeastern Turkey using SSR markers. Mitt. Klost. 2020, 70, 269-277.

50. Ozkan, G.; Ercisli, S.; Sagbas, H.I.; Ilhan, G. Diversity on fruits of wild grown European cranberrybush from Coruh valley in Turkey. Erwerbs-Obstbau 2020, 62, 275-279. [CrossRef]

51. Abbott, J.A. Quality measurement of fruits and vegetables. Postharvest Biol. Technol. 1999, 15, 207-225. [CrossRef]

52. Ma, C.; Fu, Z.; Xu, M.; Trebar, M.; Zhang, X. Evaluation on home storage performance of table grape based on sensory quality and consumers' satisfaction. J. Food Sci. Technol. 2016, 53, 1363-1370. [CrossRef] [PubMed] 